\title{
Influence of river discharge on zooplankton diet in the Godavari estuary (Bay of Bengal, Indian Ocean)
}

\author{
Jayati Mukherjee, ${ }^{1}$ Sura A. Naidu, ${ }^{1}$ V.V.S. S. Sarma,${ }^{1 *}$ Tuhin Ghosh $^{2}$ \\ ${ }^{1}$ CSIR-National Institute of Oceanography, Regional Centre, 176 Lawsons Bay Colony, Visakhapatnam; ${ }^{2}$ Jadavpur University, \\ School of Oceanographic Studies, Kolkata, India \\ *Corresponding author: sarmav@nio.org
}

\begin{abstract}
In estuaries, detrital (i.e., non-living) organic matter (OM) contributes significantly to the particulate organic matter (POM) pool and we hypothesize that it may be a major source of estuarine zooplankton diet. To test this hypothesis, the isotopic composition of carbon $\left(\delta^{13} \mathrm{C}\right)$ and nitrogen $\left(\delta^{15} \mathrm{~N}\right)$ of phytoplankton, zooplankton, and POM was assessed in the Godavari estuary (Bay of Bengal, Indian Ocean) during wet (November) and dry periods (January). As a result of higher riverine discharge, POM concentrations and values of the $\mathrm{C} / \mathrm{Chl}-a$ ratio during the wet period were higher than those measured during the dry one. Relatively lower $\delta^{13} \mathrm{C}_{\mathrm{POM}}$ values were observed during wet than dry period and contrasting to that was found for $\delta^{15} \mathrm{~N}_{\mathrm{POM}}$. Detritus from fresh water algae and $\mathrm{C}_{3}$ plants contributed significantly to the POM pool during the wet and dry period, respectively. Based on isotopic mixing model, detrital OM and phytoplankton mostly characterized the POM pools during the wet and dry periods, respectively. Accordingly, our results suggest also that the zooplankton diet was mostly supported by detrital OM during the wet period and by both phytoplankton and detrital OM during the dry one. The zooplankton trophic level (TL, 2.7) during the wet period was relatively higher than that (1.9) during the dry one, suggesting a relative higher preference for detritus than phytoplankton during the wet period. The results of this study allowed us confirming that detrital OM can significantly support zooplankton production in the Godavari estuary.
\end{abstract}

Key words: Phytoplankton, Zooplankton, detritus, stable isotopes, river discharge, Godavari estuary.

Received: December 2017. Accepted: May 2018.

\section{INTRODUCTION}

Estuarine and coastal environments are often characterized by energy sources for consumers which are heterogeneous and characterized by with large spatial and temporal variability (Stowasser et al., 2012). The trophic interactions are driven by a complex array of multiple biological, chemical and physical processes, which altogether make trophic linkages among different groups within the aquatic food web difficult to be defined (Layman et al., 2012; Stowasser et al., 2012). Such a difficulty in tracking the flow of energy along aquatic trophic webs is due to the fact that many species grow more than five orders of magnitude than others and some pass through several trophic levels during the different stages of their life cycle (Cushing, 1975; Pope et al., 1994; Post, 2002; Van Oevelen et al., 2012; Middelburg, 2014). Food web studies carried out previously relied on gut content analysis of higher trophic level organisms (Hall and Raffaelli, 1993), and this method has a limitation in assessing the assimilation of material in the gut (Stowasser et al., 2012).

Stable isotopic composition of carbon $\left(\delta^{13} \mathrm{C}\right)$ and nitrogen $\left(\delta^{15} \mathrm{~N}\right)$ can be used as complementary tools to evaluate the structure and dynamics of ecological communities (Peterson and Fry, 1987; France, 1995;
Vander-Zanden et al., 1997; Post, 2002; Middelburg, 2014; Hinz et al., 2017). These isotopes provide information about the source of material in the integrated temporal scale (Post, 2002), as $\delta^{13} \mathrm{C}$ and $\delta^{15} \mathrm{~N}$ in the tissues of predators is enriched relative to their prey, and, thus, can be used to estimate trophic levels within a certain trophic web (Minagawa and Wada, 1984; Jennings et al., 2002). The $\delta^{13} \mathrm{C}$ of consumers are usually close to that of their diet $\left(<0.5 \%\right.$; Post, 2002) whereas $\delta^{15} \mathrm{~N}$ is enriched in the consumers relative to their diet by 3.4\% (DeNiro and Epstein, 1978, 1981; Minagawa and Wada, 1984; Post, 2002). Dissimilarity in isotopic composition of $\delta^{13} \mathrm{C}$ and $\delta^{15} \mathrm{~N}$ of marine organisms are caused by selective uptake of nutrients, feeding (Meili et al., 1996; Matthews and Mazumder, 2003), and metabolic activities (DeNiro and Epstein, 1981; Hobson and Clark, 1992; Hobson et al., 2002; Matthews and Mazumder, 2006; Santer et al., 2006). Hence, the sensitivity of trophic position estimation carried out using stable isotope signatures depends on $\delta^{15} \mathrm{~N}$ and $\delta^{13} \mathrm{C}$ of end-members, which, in turn, depends by several factors such as variation in source of nutrients, dissolved inorganic carbon (DIC), organic matter etc. Obtaining an appropriate baseline is therefore one of the most challenging methodological issues facing the effective application of stable isotopes to trophic food 
web dynamics (Post, 2002; Finlay and Kendall, 2007; Hussey et al., 2014; Middelburg, 2014).

Estuaries are among the most biogeochemically active zones on the surface of the Earth (Gattuso et al., 1998; Cole et al., 2007; Richey et al., 2002; Bhavya et al., 2015) and higher rates of biological production are observed due to large nutrient inputs (Nixon et al., 1986; Kelly and Levin, 1986; Heip et al., 1995; Caffrey, 2004; Gazeau et al., 2004, 2005). Estuaries receive a considerable amount of inorganic nutrients, organic matter, contaminants from the land and exchange them with the coastal ocean (Nixon et al., 1986; Howarth et al., 1996). Besides the allochthonous sources, the active biological pump in estuaries produce significant amounts of organic matter that can accumulate both in the water column and sediments (Wollast and Mackenzie, 1989; Smith and Hollibaugh, 1993; Wollast, 1998). While it is clear that these two organic matter sinks play a key role in the trophic dynamics of estuaries, their relative importance is unclear and may be regional specific due to variable composition and (nutritional) quality of organic matter (Manini et al., 2003).

Within this framework, a significant amount of work was carried out in lakes. For instance, Lammers et al. (2017) noticed that allochthonous organic matter can contribute significantly to bacterial diet during winter, whereas in summer and fall such a contribution is very low. Strong evidence for the support of allochthonous organic matter to herbivorous zooplankton production was reported in several lakes (Grey et al., 2001; Brett et al., 2009; Cole et al., 2011). Suzuki et al. (2013), using stable isotopic composition of carbon, reported that the copepods diet in the Chikugo River estuary, Japan is supported by organic matter derived from phytoplankton ad their detrital remains. Matson and Brinson (1990), using stable isotopes of carbon, found that a significant fraction of zooplankton diet in the Pamlico and Neuse estuaries is contributed by terrestrial organic matter, and similar conclusions were made for some estuaries in Siberia (Doi et al., 2006).

Indian estuaries are characterized by runoff episodes associated with monsoonal precipitation (Vijith et al., 2009; Sridevi et al., 2015). The estuary behaves like a freshwater lake during the peak discharge period whereas seawater contribution increases during the dry period (Sridevi et al., 2015). Godavari is the largest monsoonal river in India and fed mainly by the southwest monsoonal precipitation during summer (June-September, wet period) (Acharyya et al., 2012). During the wet period, freshwater brings large amounts of inorganic nutrients, organic matter and suspended matter to the estuary (Sarma et al., 2009; 2010). During this period, despite the high nutrient concentrations, phytoplankton biomass is very low due to the high suspended load which limits light availability (Acharyya et al., 2012). Based on the values of the photosynthesis to respiration ratio, Sarma et al. (2009) estimated that $40-60 \%$ and $70-95 \%$ of the heterotrophic production is supported by organic matter of terrestrial orifin during the wet and dry periods, respectively (Gawade et al., 2017). The contribution of different taxa to the phytoplankton assemblages in the Godavari estuary varies according to the magnitude of freshwater discharge rather than to nutrient concentrations (Bharati et al., 2018). For instance, freshwater algae (e.g., Chlorophyceae) dominate during the peak freshwater discharge period (July-August). A phytoplankton bloom (mainly due to Cyanophyceae) occurs in the estuary once the river discharge decreases below $2000 \mathrm{~m}^{3} \mathrm{~s}^{-1}$ and the suspended matter load is $<200 \mathrm{mg} \mathrm{L}^{-1}$ (Bharati et al., 2018). When the freshwater discharge completely stops (January-May) due to drying of the upstream river and closing of dam gates, estuarine phytoplankton are dominated by Bacillariophyceae (diatoms) (Sarma et al., 2009, Bharati et al., 2018).

We hypothesized that the contrasting conditions between wet and dry periods and the associated variations in the composition of the potential food items may influence the zooplankton diet in the Godavari estuary. To test this hypothesis, we investigated the sources of zooplankton diet in the Godavari estuary during wet and dry periods using stable isotopic composition of carbon and nitrogen in the live and dead organic matter.

\section{METHODS}

\section{Study area}

Godavari River is located between 16 and $18^{\circ} \mathrm{N}$ latitude and originates at an altitude of about $1600 \mathrm{~m}$ near Nasik city in the Western Ghats. It flows eastwards across peninsular India for about $1480 \mathrm{~km}$ and drains into the Bay of Bengal at Bhairavapalem, on the central east coast of India (Fig. 1). Godavari is the largest monsoonal river in India and has created an extensive delta on the east coast of India. The basin climate is generally dry with an average rainfall of $1512 \mathrm{~mm} \mathrm{y}^{-1}$. The catchment receives about $82 \%$ of the annual rainfall during the summer and the rest in the winter monsoon (Central Pollution Control Board, 1995). The discharge of freshwater into the Godavari estuary is controlled by century old low dam at Dowleiswaram (Fig. 1). Discharge occurs between June and December with a peak in July-August and reduces considerably from October. After the dam, the river bifurcates into two major distributaries; the eastward flowing major tributary is called Gautami-Godavari, while the other flowing southwards is Vasistha-Godavari and the former is the major branch of river in terms of discharge. The present study was conducted in the Gautami-Godavari estuary at Yanam during 2012-2013 (Fig. 1). 


\section{Sampling}

The samples were collected during November 2012 and January 2013, assumed to represent wet and dry conditions, respectively. At each sampling date, three water samples were collected at Yanam, middle of the estuary using $5 \mathrm{~L}$ Niskin bottles operated onboard a hydrographic vessel, for the subsequent analyses of inorganic nutrients, phytoplankton biomass (in terms of chlorophyll- $a$ - Chl- $a$ - concentrations), content and isotopic composition of carbon and nitrogen in POM. About $1 \mathrm{~L}$ of water sample filtered through pre-combusted $\mathrm{GF} / \mathrm{F}$ filter for either Chl- $a$ concentrations or POM composition. An additional 1L of water sample was collected using plastic bottles for the taxonomic analysis of phytoplankton. Zooplankton samples were collected by horizontal towing using a bongo net ( $200 \mu \mathrm{m}$ pore size $)$.

\section{Chlorophyll-a analysis}

The Chl- $a$ retained on the filter was extracted with dimethyl formamide (DMF) at $4^{\circ} \mathrm{C}$ for 12 hours in the dark and the extract fluorescence was measured with a spectrofluorophotometer (Varian Instruments, Palo Alto, CA, USA) (Suzuki and Ishimaru, 1990). POM retained on the filter was first dried at $60^{\circ} \mathrm{C}$ overnight, and then kept in $\mathrm{HCl}$ acid fumes for 12 hours to remove inorganic carbon for the subsequent measurement of content and isotopic composition of carbon $\left(\delta^{13} \mathrm{C}_{\mathrm{POM}}\right)$. Acid treatment was not done on filters dedicated to the analysis of the content and isotopic composition of nitrogen $\left(\delta^{15} \mathrm{~N}_{\text {POM }}\right)$ (Goering et al., 1990; Bunn et al., 1995; Pinnegar and Polunin, 1999).

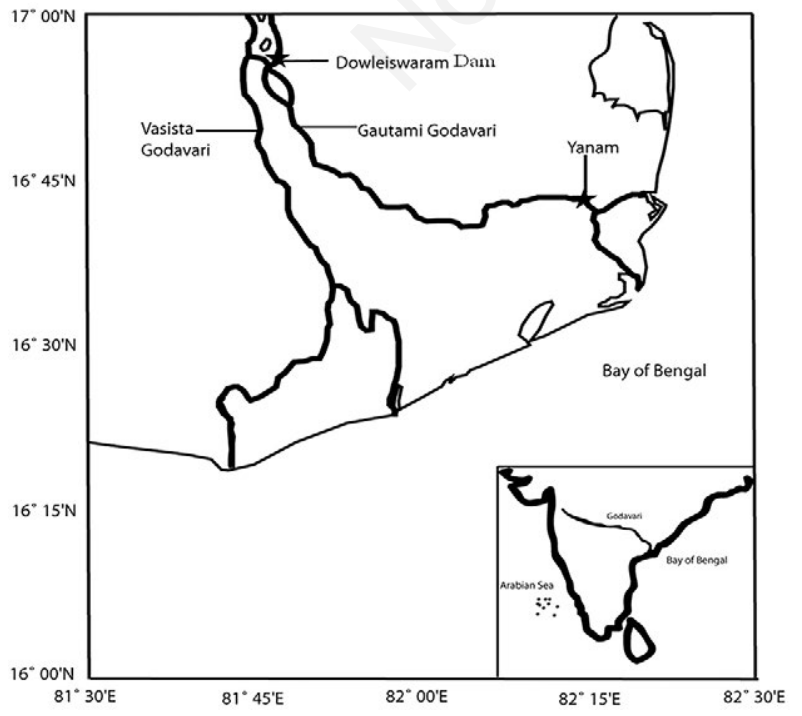

Fig. 1. The study site.

\section{Phytoplankton and zooplankton taxonomy}

Phytoplankton and zooplankton were separated under an upright microscope (4X magnification; Olympus DX 53) with the help of an injection syringe and fine needle. The specimens were cleaned with MilliQ water and subsequently transferred to tin cups and dried at $60^{\circ} \mathrm{C}$ for $12 \mathrm{~h}$. The dried tin cups were introduced to the elemental analyzer attached to the Isotope Ratio Mass Spectrometer (IRMS).

\section{Inorganic nutrient analyses}

Nutrients were analyzed following standard procedures (Grashoff et al., 1992) following colorimetric method using auto analyzer (Skalar San++, The Netherlands). The analytical precision, expressed as standard deviation, was $\pm 0.02,0.02,0.01$ and $0.02 \mu \mathrm{M}$ respectively for nitrate+nitrite, ammonium, phosphate and silicate.

\section{Stable isotope analyses}

The content and isotopic ratios of carbon and nitrogen in the samples were measured using elemental analyzer (Thermo Electron, Germany) coupled with Isotope Ratio Mass Spectrometer (IRMS - Delta V Plus, Finnigan, Germany) through Conflo IV interface, with oxidized column kept at $1050^{\circ} \mathrm{C}$ and the reduced one at $650^{\circ} \mathrm{C}$. The results are expressed as relative to conventional standards, i.e., PDB for carbon (Coplen, 1996) and atmospheric $\mathrm{N}_{2}$ for nitrogen (Mariotti, 1983) as $\delta$ values, defined as:

$\delta \mathrm{R}=\left[\mathrm{X}_{\text {sample }}-\mathrm{X}_{\text {standard }}\right) / \mathrm{X}_{\text {standard }}{ }^{*} 1000(\%)$

where, $\mathrm{R}={ }^{13} \mathrm{C}$ or ${ }^{15} \mathrm{~N}$, and $\mathrm{X}={ }^{13} \mathrm{C} /{ }^{12} \mathrm{C}$ or ${ }^{15} \mathrm{~N} /{ }^{14} \mathrm{~N}$. Highpurity $\mathrm{CO}_{2}$ and $\mathrm{N}_{2}$ gases were used as working standards for carbon and nitrogen, respectively. These gases were calibrated with internal reference materials of glutamic acid, alanine and marine sediment and international standards obtained from the International Atomic Energy Agency (IAEA). The standard deviation on 20 aliquots of the same samples was $<0.2 \%$ for both $\delta^{13} \mathrm{C}$ and $\delta^{15} \mathrm{~N}$.

The trophic level (TL) was estimated using $\delta^{15} \mathrm{~N}$ isotopic values using the expression proposed by Post (2002):

$$
\mathrm{TL}=\lambda+\left(\delta^{15} \mathrm{~N}_{\text {consumer }}-\left[\delta^{15} \mathrm{~N}_{\text {basel }} \mathrm{x} \alpha+\delta^{15} \mathrm{~N}_{\text {base2 }} \mathrm{x}(1-\alpha)\right]\right) / 3.4
$$

where, $\delta^{15} \mathrm{~N}_{\text {consumer }}$ is the nitrogen isotopic ratio of the zooplankton. $\delta^{15} \mathrm{~N}_{\text {base1 }}$ and $\delta^{15} \mathrm{~N}_{\text {base2 } 2}$ are the isotopic composition of base 1 (phytoplankton) and base 1 (detritus), respectively. 1 is trophic position of the organism used to estimate $\delta^{15} \mathrm{~N}_{\text {base }}$ and it is 1 for primary producers. $\alpha$ is the proportion of nitrogen derived from the base of food web one (base 1) to consumer (Post, 
2002). When the movement of nitrogen and carbon through the food web is similar, $\alpha$ can be estimated using carbon isotopes - $\alpha=\left(\delta^{13} \mathrm{C}_{\text {consumer }}-\delta^{13} \mathrm{C}_{\text {base } 2}\right) /\left(\delta^{13} \mathrm{C}_{\text {basel }}\right.$ $\left.\delta^{13} \mathrm{C}_{\text {base } 2}\right)$ (Post, 2002).

\section{Sources of the zooplankton diet}

The relative contribution of variable sources of food to consumers was quantified using isotope mixing model 'SIAR' (Stable Isotope Analysis in R), an open source package (http://cran.r-project.org/), which resolves mixture within a Bayesian framework (Parnell et al., $2008,2010)$. This model includes standard deviation as a residual error term to compute the variability (Jackson et al., 2009; Parnell et al., 2010). A detailed description of the model is given elsewhere (Sarma et al., 2014). The selection of isotopic composition of the source is critical for the estimation of proportional contributions to consumers. Mean isotopic ratios of $\delta^{13} \mathrm{C}$ and $\delta^{15} \mathrm{~N}$ of several end members $\left(\mathrm{C}_{3}\right.$ and $\mathrm{C}_{4}$ terrestrial plants, soil organic matter, fresh water algae, marine phytoplankton, estuarine phytoplankton, zooplankton) from drainage basin of the Godavari river were measured (Tab. 1) to separate and determine the percentage contribution of the live (autochthonous/in situ phytoplankton) and the detritral fractions (allochthonous/ex situ, dead organic matter) to the POM (Krishna et al., 2015). The freshwater algae were separated under the microscope from water samples collected from the upstream Godavari estuary (close to the dam) for fixing end members of in-situ sources. The end member values are close to those estimated elsewhere in other estuaries (Hamilton and Lewis, 1992; Middelburg and Nieuweuwenhuize, 1998; Barth et al., 1998; Hellings et al., 1999; Kao and Liu, 2000; Boschker et al., 2005; Bontes et al., 2006).

\section{RESULTS}

\section{Water column variables}

Due to variable river discharge, hydrographic conditions varied considerably between the wet (JuneDecember) and dry (January-May) periods. During the wet period, the mean river discharge to the Godavari estuary was relatively weak $\left(\sim 825 \mathrm{~m}^{3} \mathrm{~s}^{-1}\right.$, on average), whereas no discharge at all occurred during the dry period (January). As a result of the weak discharge during the wet period, a strong stratification occurred in the estuary with low salinity waters $(9.236)$ constrained at the surface and high salinity waters at the bottom (27.631). In contrast, during the dry period, high salinity (27.236) values characterized the entire water column. The highest concentrations of nutrients (nitrate, ammonium, phosphate and silicate of 10.9, 15.30, 2.91 and $52.82 \mu \mathrm{M}$ respectively) were observed during the wet period, whereas values measured during the dry period were up to 5-10 times lower (1.8, 1.4, 0.9 and $10.3 \mu \mathrm{M}$, respectively). Particulate organic C (POC) concentrations were significantly higher $(t$-test, $\mathrm{t}=245.1$; $\mathrm{P}<0.001)$ during the wet period $\left(3608 \pm 117 \mu \mathrm{gC} \mathrm{L}^{-1}\right)$ than during the dry one $\left(1284 \pm 67 \mu \mathrm{gC} \mathrm{L}^{-1}\right)$. The $\mathrm{C}: \mathrm{N}$ ratio values of POM were significantly $(t$-test; $\mathrm{t}=31.6$; $\mathrm{P}<0.001)$ higher during the wet $(19.4 \pm 3)$ than the dry

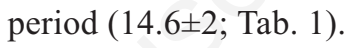

\section{Phytoplankton abundance, biomass and assemblage composition}

Phytoplankton abundance was lower $(t$-test; $\mathrm{t}=-\mathbf{7 0 . 4}$; $\mathrm{P}<0.001)$ during the wet period $\left(44253\right.$ cell $\left.\mathrm{L}^{-1}\right)$ than during the dry one (63684 cell L L phytoplankton biomass was significantly higher ( $t$-test; $\mathrm{t}=25.8 ; \mathrm{P}<0.001)$ during the wet period $(10.5 \pm 2 \mu \mathrm{g}$ Chl- $a$ $\left.\mathrm{L}^{-1}\right)$ than during the dry one $\left(4.7 \pm 1 \mu \mathrm{g} \mathrm{Chl-} a \mathrm{~L}^{-1}\right)$ (Tab. 2 ). Values of the POC/Chl- $a$ ratio were higher during the wet (343) than the dry period (271) ( $t$-test; $\mathrm{t}=34.6$; $\mathrm{P}<0.001)$. During the wet period, the phytoplankton assemblage was dominated by Cyanophyceae (mostly Merismopedia sp. and Gleocapsa sp.; overall $47 \%$ of the total phytoplankton abundance), followed by Chlorophyceae (33\%; mostly Actinastrum sp., Scenedesmus sp., Pediastrum sp.), small $(<10 \mu \mathrm{m})$ diatoms (19\%, Leptocylindrus sp., Coscinodiscus sp.) and Dinophyceae (1\%). During the dry period small size diatoms (mostly Coscinodiscus sp., Chaetoceros sp. and Ceratium $s p$.) represented up to $95 \%$ of the total phytoplankton abundance.

Tab. 1. The isotopic composition of different sources of organic matter used in the SIAR model.

\begin{tabular}{lccc} 
Source & $\boldsymbol{\delta}^{13} \mathbf{C}(\%)$ & $\delta^{15} \mathbf{N}(\%)$ & Keference \\
$\mathrm{C}_{3}$ plants & $-25.9 \pm 1.2$ & $5.1 \pm 2.1$ & Krishna et al., 2015 \\
$\mathrm{C}_{4}$ plants & $-13.1 \pm 1.2$ & $4.4 \pm 2.1$ & Krishna et al., 2015 \\
\hline Marine phytoplankton & $-23.6 \pm 0.3$ & $9.2 \pm 0.8$ & Krishna et al., 2015 \\
Soil organic matter & $-19.2 \pm 2.4$ & $10.3 \pm 2.7$ & Krishna et al., 2015 \\
\hline Freshwater algae & $-33.1 \pm 2.3$ & $6.8 \pm 0.8$ & This study \\
\hline
\end{tabular}




\section{Zooplankton abundance and community composition}

Mesozooplankton abundance was relatively lower during the dry (105 ind. $\mathrm{m}^{-3}$ ) than the wet period (188 ind. $\left.\mathrm{m}^{-3}\right)$. During the wet period the mesozooplankton assemblage consisted mostly of copepods ( $85 \%$ of the total zooplankton abundance) and other, less abundant, taxa were Cladocera, Gastropod veliger, Nauplii, Tellina sp, and Zoea (cumulatively representing $15 \%$ of the total abundance). Calanoida represented up to $90 \%$ of the total zooplankton abundance, followed by Cyclopoida (5\%), Harpacticoida (3\%) and Polycheate larvae (2\%). During the dry period, Copepods (Calanoida, Cyclopoida and Harpacticoida) were the most abundant (92\% of the total mesozooplankton abundance), followed by Zoea, Decapoda, and Harpacticoid Copepoda (cumulatively $8 \%$ ).

\section{Isotopic composition of phytoplankton and zooplankton}

The isotopic composition of carbon in the different phytoplankton taxa ranged between -28.1 and $-24.9 \%$ and a relatively higher value characterized Cyanophyceae (-28.1\%) during the wet period (Tab. 3). The mean $\delta^{13} \mathrm{C}\left(\delta^{15} \mathrm{~N}\right)$ of phytoplankton was significantly lower (higher) ( $t$-test; $\mathrm{t}=-8.9 ; \mathrm{P}<0.01$ and $\mathrm{t}=53.21$; $\mathrm{P}<0.01$, respectively) during the wet $(-26.1 \pm 1.4 \%$ and $15.9 \pm 2.5 \%$ respectively) than the dry period ($24.6 \pm 0.6 \%$ and $4.6 \pm 1.0 \%$ respectively) (Tab. 2 ). The isotopic composition of $\delta^{13} \mathrm{C}$ and $\delta^{15} \mathrm{~N}$ of mesozooplankton ranged from -29.3 to $-29.1 \%$ and 13.9 to $15.2 \%$, respectively during wet period (Tab. 3), and from -23.8 to $-22.2 \%$ and 6.9 to $8.4 \%$ during the dry one (Tab. 3). The $\delta^{13} \mathrm{C}\left(\delta^{15} \mathrm{~N}\right)$ of mesozooplankton during the dry period was significantly higher (lower) during the wet one $(t$-Test; $\mathrm{t}=-44.3 ; \mathrm{P}<0.001$ and $\mathrm{t}=140.5$; $\mathrm{P}<0.001$, respectively; Tab. 2).

\section{Sources and isotopic composition of POM and detritus}

The $\delta^{13} \mathrm{C}$ and $\delta^{15} \mathrm{~N}$ of POM was relatively lighter during the wet (-31.2\%o and $4.9 \%$ ) than the dry period ($25.6 \%$ and $6.4 \%$ ). The results obtained from the SIAR model suggest that 17 and $25 \%$ of POM was contributed by live organic matter during the wet and dry periods, respectively (Tab. 4). During the wet period freshwater algae contributed the most $69 \%$ ) to detritus, followed by $\mathrm{C}_{3}$ plants $(9 \%)$, whereas during the dry periods $\mathrm{C}_{3}$ plants $(60 \%)$ were the most important contributors to detritus, followed by estuarine phytoplankton (14\%) and freshwater algae (12\%) (Tab. 4).

During the wet period the isotopic composition of carbon in detritus $\left(\delta^{13} \mathrm{C}_{\mathrm{det}}\right)$, resembling that of freshwater algae, was significantly $(t$-test; $\mathrm{t}=-56.5 ; \mathrm{P}<0.001)$ depleted $(-31.7 \pm 1.4 \%)$, when compared to that measured during the dry one $(-25.9 \pm 1.3 \%$; Tab. 2). The isotopic composition of nitrogen in detritus $\left(\delta^{15} \mathrm{~N}_{\mathrm{det}}\right)$ was significantly higher $(t$-test; $\mathrm{t}=5.9 ; \mathrm{P}<0.01)$ during the wet period $(6.5 \pm 3.7 \%$ ) than the dry one $(5.3 \pm 1.3 \%$; Tab. 2$)$.

\section{Trophic levels and food web structure}

During the wet period, due to the higher $\delta^{15} \mathrm{~N}_{\text {phytoplankton, }}$ the $\delta^{15} \mathrm{~N}_{\text {base }}$ values for consumers were enriched (10.3 and $7.5 \%$ ) when compared to those estimated during the dry one (4.9 and 6.2\%o respectively). During the wet period, the estimated TL for Calanoida and Cyclopoida was 2.6 and 2.7, respectively and decreased (1.8 and 2.0, respectively) during the dry period (Tab. 5). The mean TL

Tab. 2. Mean concentrations and isotopic values of several components of the Godavari estuary ecosystem during wet and dry.

\begin{tabular}{lccc} 
Property & Wet period & Dry period & $t$-test and P-value \\
Discharge $\left(\mathrm{m}^{3} \mathrm{~s}^{-1}\right)$ & $825 \pm 80$ & 0 & $142.04 ;<0.001$ \\
Chlorophyll-a $\left(\mu \mathrm{g} \mathrm{L}^{-1}\right)$ & $10.5 \pm 2$ & $4.7 \pm 1$ & $25.88 ;<0.001$ \\
\hline POM $\left(\mu \mathrm{gC} \mathrm{L}^{-1}\right)$ & $3608 \pm 117$ & $1284 \pm 67$ & $245.15 ;<0.001$ \\
PON $\left(\mu \mathrm{gN} \mathrm{L}^{-1}\right)$ & $238 \pm 3.2$ & $210 \pm 2.9$ & $11.17 ;<0.001$ \\
\hline $\mathrm{C} / \mathrm{N}$ & $19.4 \pm 3$ & $14.6 \pm 2$ & $31.64 ;<0.001$ \\
Phytoplankton abundance (cells/L) & 44253 & 63684 & $-70.40 ;<0.001$ \\
\hline POC/Chl & $343 \pm 18$ & $271 \pm 12$ & $34.60 ;<0.001$ \\
Dominant group & Cyanophyceae & $-25.9 \pm 1.3$ & - \\
\hline$\delta^{13} \mathrm{CDetritus}(\%)$ & $-31.7 \pm 1.4$ & $5.3 \pm 1.3$ & $-56.51 ;<0.001$ \\
$\left.\delta^{15} \mathrm{NDetritus} \mathrm{( \% )}\right)$ & $6.5 \pm 3.7$ & $-24.6 \pm 0.6$ & $5.87 ;<0.01$ \\
\hline$\delta^{13} \mathrm{CPhytoplankton}(\%)$ & $-26.1 \pm 1.4$ & $4.6 \pm 1.0$ & $-8.96 ;<0.01$ \\
$\delta^{15} \mathrm{NPhytoplankton}(\%)$ & $15.9 \pm 2.5$ & $-23.3 \pm 0.8$ & $53.21 ;<0.001$ \\
\hline$\delta^{13} \mathrm{CZooplankton}(\%)$ & $-29.1 \pm 0.1$ & $7.9 \pm 0.7$ & $-44.31 ;<0.001$ \\
$\delta^{15} \mathrm{NZooplankton}(\%)$ & $14.5 \pm 0.6$ & $140.48 ;<0.001$
\end{tabular}


for zooplankton was 2.7 and 1.9 during the wet and dry periods, respectively.

\section{DISCUSSION}

\section{Variable sources of POM during the wet and dry periods}

The carbon to nitrogen $(\mathrm{C}: \mathrm{N})$ ratio is a trace to identify source of organic matter as it varies for variable sources such as plankton (6-7), bacteria (4-5), and organic matter from higher plants (>20) (Hedges et al., 1997). However, several diagenetic processes can modify $\mathrm{C}: \mathrm{N}$ ratios which lower its viability to identify the actual sources of organic matter. For instance, $\mathrm{C}: \mathrm{N}$ ratio of higher plant litter typically decreases due to bacterial colonization, and increases in senescent or dead algae due to the preferential removal of nitrogen by consumers (Hedges et al., 1997; Herman and Heip, 1999). Nonetheless, though such biases do not allow identifying the exact source of organic matter, variations in the $\mathrm{C}: \mathrm{N}$ ratio values can provide some indication on changes occurring in $\mathrm{OM}$ origin and

Tab. 3. Isotopic composition of sources, primary, secondary and tertiary consumers and trophic level of primary and secondary consumers during the wet and dry periods.

\begin{tabular}{|c|c|c|c|c|}
\hline \multirow[t]{2}{*}{ Source/consumer } & Groups & $\delta^{13} \mathrm{C}(\%)$ & $\delta^{15} \mathbf{N}(\% 0)$ & TL \\
\hline & Wet period & & & \\
\hline \multirow[t]{3}{*}{ Source } & Phytoplankton* & $-26.1 \pm 0.9$ & $15.9 \pm 2.5$ & \\
\hline & Detritus & $-31.7 \pm 1.4$ & $6.5 \pm 3.7$ & \\
\hline & Soil organic matter & $-23.5 \pm 1.1$ & $6.0 \pm 0.9$ & \\
\hline \multirow[t]{4}{*}{ Zooplankton } & Calanoida (10) & $-29.3 \pm 1.2$ & $13.9 \pm 2.5$ & 2.6 \\
\hline & Cyclopoida (21) & $-29.1 \pm 0.6$ & $14.5 \pm 3.4$ & 2.7 \\
\hline & Cladocera (11) & $-29.2 \pm 0.5$ & $15.2 \pm 0.3$ & 2.9 \\
\hline & Dry period & & & \\
\hline \multirow[t]{3}{*}{ Source } & Phytoplankton (100) & $-24.6 \pm 0.4$ & $4.6 \pm 1.0$ & \\
\hline & Detritus & $-25.9 \pm 1.2$ & $5.3 \pm 1.3$ & \\
\hline & Soil organic matter & $-23.1 \pm 0.8$ & $6.3 \pm 0.5$ & \\
\hline \multirow[t]{5}{*}{ Zooplankton } & Harpacticoida (14) & $-22.5 \pm 0.3$ & $7.4 \pm 0.6$ & 1.8 \\
\hline & Cyclopoida (25) & $-24.2 \pm 0.6$ & $6.9 \pm 0.8$ & 1.6 \\
\hline & Zoea (25) & $-22.2 \pm 0.5$ & $8.0 \pm 0.5$ & 2.0 \\
\hline & Calanoida (25) & $-23.8 \pm 0.5$ & $8.2 \pm 0.3$ & 2.0 \\
\hline & Decapoda (16) & $-23.4 \pm 0.8$ & $8.1 \pm 0.4$ & 2.0 \\
\hline
\end{tabular}

TL, Trophic level; "nearly 100 number of phytoplankton cells were analyzed.

Tab. 4. Proportion (\%) of source contributors to the particulate organic matter pool in the Godavari estuary based on the outputs of the SIAR model.

\begin{tabular}{llcc} 
POM & Period & Wet period & Dry period \\
Live fraction & Phytoplankton & 7 & 14 \\
Zooplankton & & 8 & 7 \\
\hline Marine algae & Freshwater algae & 3 & 3 \\
\hline Detrital fraction & C3 plants & 69 & 12 \\
& C4 plants & 9 & 60 \\
\hline
\end{tabular}

POM, Particulate organic matter.

Tab. 5. Contribution (\%) of detritus and phytoplankton to the zooplankton diet in the Godavari estuary based on SIAR model.

\begin{tabular}{llcc} 
Consumers & Period & Detritus & Phytoplankton \\
Zooplankton & Wet & 60 & 40 \\
Zooplankton & Dry & 40 & 60 \\
\hline
\end{tabular}


diagenetic status (Middelburg and Herman, 2007). The higher values of the $\mathrm{C}: \mathrm{N}$ ratio values of POM observed during the wet period (Tab. 1) suggest that during this period the Godavari estuary was characterized by a relevant fraction of non-living organic matter.

The POC:Chl- $a$ ratio (C:Chl- $a$ ) can also be used to delineate the sources of organic matter as relatively lower values are associated with freshly derived organic matter by in situ biological production, whereas higher values are associated with older and degraded OM (Cifuentes et al., 1988; Richard et al., 1997; Bentaleb et al., 1998). In fact, the C:Chl- $a$ ratio of fresh organic matter produced by marine phytoplankton varies from $\sim 40$ (Montagnes et al., 1994), <70 (Geider, 1987) <100 (Head et al., 1996), <140 (Thompson et al., 1992) to <200 (Cifuentes et al., 1988; Bentaleb et al., 1998) also according to regional temperature and irradiance regimes, as well as species growth rates and composition (Heath et al., 1990; Montagnes et al., 1994; Geider et al., 1998). In our study, the C:Chl- $a$ ratio during the wet $(343 \pm 18)$ and dry $(271 \pm 12)$ period were consistently $>200$, suggesting the presence in both periods of a relevant fraction of terrestrial OM sources, more evidently during the wet period (Tab. 2), as previously reported from other Indian estuaries (Sarma et al., 2014).

The output of the SIAR model suggests that 18 and $24 \%$ (wet and dry period, respectively) of the POM was contributed by live OM, also that the contribution of detrital OM was high during both study periods (Tab. 4). Such low contribution of live OM was caused by the minimal photic depth (0.1 to $2 \mathrm{~m}$; Sarma et al., 2009) which likely limited primary production. During the wet period, the $\delta^{13} \mathrm{C}_{\text {detritus }}(-31.7 \pm 1.4 \%$ ) is close to that of freshwater algae (-33.2\%; Tab. 1), suggesting that dead freshwater algae contributed significantly to the detritus pool. During the wet period, apart from estuarine phytoplankton, the estuary received organic matter also from terrestrial sources, such as $\mathrm{C}_{3}, \mathrm{C}_{4}$ land plants and soil OM (Sarma et al., 2014). Moreover, the output of the SIAR model suggests that, during the wet period, $69 \%$ of the detritus was contributed by freshwater algae and $9 \%$ by $\mathrm{C}_{3}$ plants (Tab. 4).

The accumulation of detritus in the water column depends also upon the residence time of water in the estuary. The residence time of water in the Godavari estuary is $<1 \mathrm{~d}$ during the peak discharge and increases up to $>30 \mathrm{~d}$ during the dry period. However, also when a moderate discharge occurs (November, wet period) the residence time of estuarine water is $>20 \mathrm{~d}$ (Sridevi et al., 2015). Moreover, during November, freshwater phytoplankton blooms have been also reported in the Dowleiswaram dam reservoir waters (Prasad et al., 2013), which could have been injected into the estuary along with freshwater discharge during the wet period. The combination of varying residence times and the potential input of waters from the dam can be reasonably invoked to explain the relative importance of dead freshwater contribution to the detritus pool during the wet period. On the other hand, during the dry period, $\sim 60 \%$ of detritus was contributed by $\mathrm{C}_{3}$ plants and $12 \%$ by freshwater algae. Despite the negligible amount of discharge during the dry period a certain amount of terrestrial OM, brought during discharge period, might have been trapped in the estuary due to high residence time of water and recirculation through tidal mixing.

Thus, the results of our study suggest that during both wet and dry periods the contribution of in situ phytoplankton to POM in the Godavari estuary is very small when compared to allochthonous OM sources, like terrestrial OM or freshwater algae.

\section{Potential sources of nutrients for phytoplankton}

The $\delta^{15} \mathrm{~N}_{\text {phytoplankton }}$ was significantly heavier (15.9 \pm 2.5 $\%$ ) during wet period than earlier reports from the Godavari estuary (5.1 to $7.8 \%$; Sarma et al., 2012, 2014). Such heavier $\delta^{15} \mathrm{~N}_{\text {phytoplankton }}$ were normally observed in highly polluted estuaries (up to 23\%; Middelburg and Herman, 2007; Kromkamp et al., 1995) and were at times attributed to the high chemoautotrophic production rates by nitrifiers (Soetaert and Herman, 1995a, 1995b). Owens (1985) noticed enriched $\delta^{15} \mathrm{~N}$ of PN (14.7\%o) in the suspended matter at the turbidity maximum zone and attributed it to intense biological processing of OM. Seasonal enrichment of $\delta^{15} \mathrm{~N}_{\text {POM }}$ (18-24\%) has been also reported repeatedly during spring in several other estuaries (Middelburg and Herman, 2007), and attributed to the utilization of isotopically enriched nitrogen, especially residual ammonium resulted from nitrification (Mariotti et al., 1984) or extensive algal uptake of nitrogen, leading to enrichment of leftover nitrogen.

The occurrence of phytoplankton blooms associated with rapid decrease in DIN concentrations was reported a month prior to our sampling (Sarma et al., 2009). Based on previous studies conducted in other estuaries, we can hypothesize that in our study $\delta^{15} \mathrm{~N}_{\text {DIN }}$ might be enriched in October due to the extensive utilization of lighter inorganic nitrogen available in association with the phytoplankton bloom and that the uptake of such enriched $\delta^{15} \mathrm{~N}_{\text {DIN }}$ might have increased isotopic value of phytoplankton during the wet period.

Though the detritus pool includes phytoplankton biomass, during the dry period the $\delta^{15} \mathrm{~N}_{\text {POM }}$ were lower than $\delta^{15} \mathrm{~N}_{\text {phytoplankton }}$ suggesting that the contribution of the latter may be less than the former. On the other hand, during the dry period, $\delta^{15} \mathrm{~N}_{\text {Phytoplankton }}(4.6 \pm 1.0 \%$ ) was close to that of the nutrients derived from regeneration of marine organic matter (4.8\%; Sigman et al., 2000) suggesting that regenerated nutrients might have supported phytoplankton biomass during the dry period. 


\section{Potential sources for the zooplankton diet}

The output of the SIAR model suggests that zooplankton based for their diet preferentially $(60 \%)$ on detritus than phytoplankton (40\%) during the wet period, and inverted such preference during the dry one (Tab. 5). Despite during the wet period higher phytoplankton biomass was observed (10.5 $\pm 2 \mu \mathrm{g}$ Chl- $\left.a \mathrm{~L}^{-1}\right)$ zooplankton preferred detritus as a food source. In this regard, however, it is worth noting that the detritus pool during the wet period contained an important fraction of freshwater dead/senescent algae, likely providing a labile source of food as the one provided by phytoplankton biomass. During the dry period, instead, the preference of zooplankton for phytoplankton $(60 \%)$ depended most likely by the availability of larger size phytoplankton.

\section{Trophic level of food web during wet and dry periods}

The computed TL for zooplankton (Calanoida, and Cyclopoida) was 2.6-2.9 during the wet period and decreased (1.6-2.0) during the dry one (Tab. 3). Such a difference can be attributable to variations in the base of the food web. In fact, during the dry period, when phytoplankton represented a relevant proportion of the zooplankton diet, the TL for primary consumers was low, whereas the more important contribution of detritus during the wet period resulted in a higher TL (Tab. 3). These results are also consistent with the variations in the relative importance of detritus $v s$ phytoplankton to the zooplankton diet between the two sampling periods. Variations in the relative importance of detritus (40\% vs $60 \%$ in the dry and wet periods, respectively), were also associated with changes in the relative importance of detritus from $\mathrm{C}_{3}$ plants (prevailing during the dry period) and freshwater algae (prevailing in the wet period) (Tab. 4).

\section{CONCLUSIONS}

Our results confirm previous findings showing that mesozooplankton can modify their TL in response to natural environmental changes, resulting, in turn, in expansions or contractions in trophic linkages within the food web and, as a consequence, affecting the efficiency of energy transfer in food webs (Decima et al., 2013). For instance, Landry (1981) reported that several species may alter their dietary compositions and TL within the food web as a consequence of changes in the size structure and availability of phytoplankton with a preference for larger cells (Frost, 1972; Landry, 1981; Ohman and Runge, 1994), either as a passive response to relative availability of alternate prey or an active switching tendency toward omnivory, when mean phytoplankton size is smaller (Calbet and Landry, 1999).

As changes in TL of primary consumers affect, by cascade, the trophic position of consumers at higher
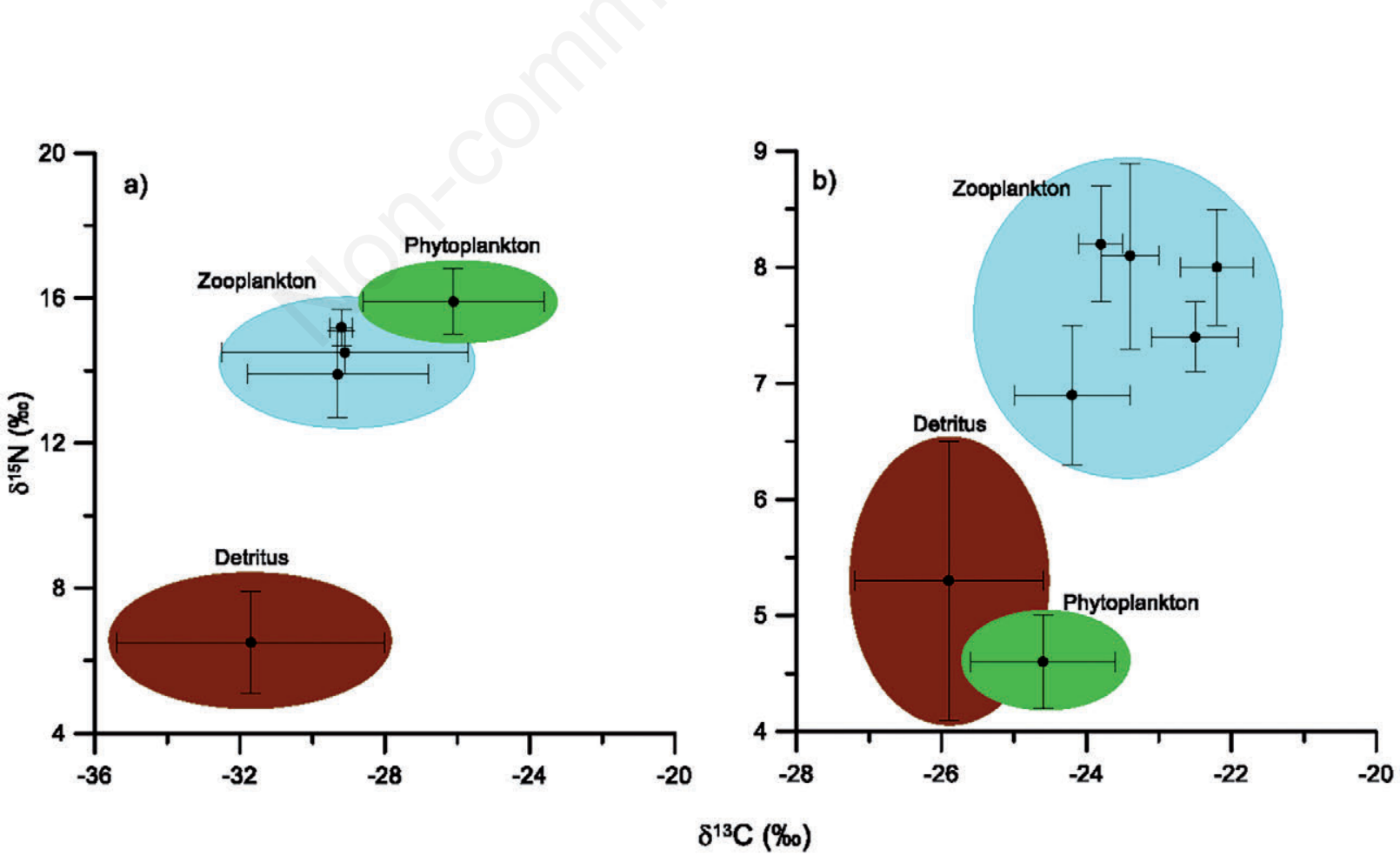

Fig. 2. The isotopic composition of carbon and nitrogen of phytoplankton, detritus and zooplankton during wet (a) and dry (b) periods in the Godavari estuary. 
trophic levels, our results, based on the estimates of the trophic position through $\delta^{15} \mathrm{~N}$ isotopic values, suggest the presence of a food chain that is longer during the dry than the wet period (Fig. 2).

Although based on an under-replicated study, we conclude that changes in the structure (length) of the food chain in the Godavari estuary reported here were plausibly determined by variations in the array of environmental factors, which, in turn, affected the origin, composition and food availability of POM at the base of the food web and, by cascade, the zooplankton diet.

\section{ACKNOWLEDGMENTS}

We thank the Director, National Institute of Oceanography (NIO), Goa, the Scientist-In-Charge, NIORegional Centre, Visakhapatnam and Dr. A.C. Anil, DU Leader, for their support and encouragement. The work was carried out under the Council of Scientific and Industrial Research (CSIR), Government of India funded project (Ocean Finder, PSC 0105). We also thank the boat personnel for their help during field trip. We would like to acknowledge Mr. P. Praveen Kumar and G. Srikanth for their help during measurements on IRMS.

We would like to thank two anonymous reviewers and Editor-in-Chief for their constructive criticism to improve presentation of this manuscript.

\section{REFERENCES}

Acharyya T, Sarma VVSS, Sridevi B, Venkataramana V, Bharathi MD, Naidu SA, Kumar BSK, Prasad VR, Bandopadhyay D, Reddy NPC, Kumar MD, 2012. Reduced river discharge intensifies phytoplankton bloom in Godavari estuary, India. Mar. Chem. 132-133:15-22.

Barth JAC, Veizer J, Mayer B, 1998. Origin of particulate organic carbon in the upper St.Lawrence: Isotopic constraints. Earth Planet. Sci. Lett. 162:11-121.

Bentaleb I, Fontugne M, Descolas-Gros C, Girardin C, Mariotti A, Pierre C, Brunet C, Poisson A, 1998. Carbon isotopicfractionation by plankton in the Southern Indian Ocean: relation between $\delta^{13} \mathrm{C}$ of particulate organic carbon and dissolved carbon dioxide. J. Marine Syst. 17:39-58.

Bharati MD, Sarma VVSS, Ramaneswari K, 2018. Intra-annual variations in phytoplankton biomass and its composition in the tropical estuary: Influence of river discharge. Mar. Pollut. Bull. 129:14-25.

Bhavya PS, Kumar S, Gupta GVM, Sudheesh V, Sudharma KV, Varrier, DS, Dhanya, KR, Saravanane N, 2015. Nitrogen uptake dynamics in a tropical eutrophic estuary (Cochin, India) and adjacent coastal waters. Estuar. Coast. 39:4-67.

Bontes BM, Pel R, Ibelings BW, Boschker HTS, Middelburg JJ, Van Donk E, 2006. The effects of biomanipulation on the biogeochemistry, carbon isotopic composition and pelagic food web relations of a shallow lake. Biogeosciences 3:69-83.

Boschker HTS, Middelburg JJ, Kromkamp J, 2005. Biomarker and carbon isotopic constraints on bacterial and algal community structure and functioning in a turbid, tidal estuary. Limnol. Oceanogr. 50:70-80.

Brett MT, Kainz MJ, Taipale SJ, Seshan H, 2009. Phytoplankton, not allochthonous carbon, sustains herbivorous zooplankton production. P. Natl. Acad. Sci. USA 106:21197-21201.

Bunn SE, Loneragan NR, Kempster MA, 1995. Effects of acid washing on stable isotope ratios of $\mathrm{C}$ and $\mathrm{N}$ in penaeid shrimp and seagrass: implications for food-web studies using multiple stable isotopes. Limnol. Oceanogr. 40:622-625.

Caffrey JM, 2004. Factors controlling net ecosystem metabolism in US estuaries. Estuaries 27:90-101.

Calbet A, Landry MR, 1999. Mesozooplankton influences on the microbial food web: Direct and indirect trophic interactions in the oligotrophic open ocean. Limnol. Oceanogr. 44:1370-1380.

Central Pollution Control Board, 1995. Basin sub-basin inventory of water pollution Godavari Basin. CPCB, Delhi.

Cifuentes AA, Sharp JH, Fogel ML, 1988. Stable carbon and nitrogen isotope biogeochemistry in the Delaware estuary. Limnol. Oceanogr. 33:1102-1115.

Cole JJ, Prairie YT, Caraco NF, McDowell WH, Tranvik LJ, Striegl, RG, Duarte CM, Kortelainen P, Downing JA, Middelburg JJ, Melack J, 2007. Plumbing the global carbon cycle: Integrating inland waters into the terrestrial carbon budget. Ecosystems 10:171-184.

Cole JJ, Carpenter SR, Kitchell JF, Pace ML, Solomon CT, Weidel BC, 2011. Strong evidence for terrestrial support of zooplankton in small lakes based on stable isotopes of carbon, nitrogen, and hydrogen. P. Natl. Acad. Sci. USA 108:1975-1980.

Coplen TB, 1996. New guidelines for reporting stable hydrogen, carbon and oxygen isotope-ratio data. Geochim. Cosmochim. Acta 60:3359-3360.

Cushing DH, 1975. Marine ecology and fisheries. Cambridge University Press, Cambridge: 278 pp.

Decima M, Landry MR, Popp B, 2013. Environmental perturbation effects on baseline $\mathrm{d} 15 \mathrm{~N}$ values and zooplankton trophic flexibility in the southern California current ecosystem. Limnol. Oceanogr. 58:624-634.

DeNiro MJ, Epstein S, 1978. Influence of diet on the distribution of carbon isotopes in animals. Geochim. Cosmochim. Acta 42:495-506.

DeNiro MJ, Epstein S, 1981. Influence of diet on the distribution of nitrogen isotopes in animals. Geochim. Cosmochim. Acta 45:341-351.

Doi H, Zuykova EI, Kikuchi E, Shikano S, Kanou K, Yurlova N, Yadrenkina E, 2006. Spatial changes in carbon and nitrogen stable isotopes of the plankton food web in a saline lake ecosystem. Hydrobiologia. 571:395-400.

Finlay JC, Kendall C, 2008. Stable isotope tracing of temporal and spatial variability in organic matter sources to freshwater ecosystems, p. 283-333. In: R. Michener and K. Lajtha (eds.), Stable isotopes in ecology and environmental sciences. Blackwell Publishing Ltd., Malden.

France R, 1995. Critical examination of stable isotope analysis as a means for tracing carbon pathways in stream ecosystems. Can. J. Fish. Aquat. Sci. 52:651-656.

Frost BW, 1972. Effects of size and concentration of food 
particles on feeding behavior of marine planktonic copepod Calanus pacificus. Limnol. Oceanogr. 17:805-815.

Gattuso JP, Frankignoulle M, Wollast R, 1998. Carbon and carbonate metabolism in coastal aquatic ecosystems. Ann. Rev. Ecol. Evol. S. 29: 405-434.

Gawade L, Sarma VVSS, Rao YV, Hemalatha KPJ, 2017. Variation of bacterial metabolic arates and organic matter in the monsoon-affected tropical estuary (Godavari, India). Geomicrobiol. J. 34:628-640.

Gazeau F, Smith SV, Gentili, B, Frankignoulle M, Gattuso JP, 2004. The European coastal zone: Characterization and first assessment of ecosystem metabolism. Estuar. Coast. Shelf Sci. 60:673-694.

Gazeau F, Borges AV, Barron C, Duarte CM, Iversen N, Middelburg JJ, Delille B, Pizay MD, Frankignoulle M, Gattuso JP, 2005. Net ecosystem metabolism in a micro-tidal estuary (Randers Fjord, Denmark): Evaluation of methods. Mar. Ecol. Prog. Ser. 301:23-41.

Geider RJ, 1987. Light and temperature dependence of the carbon to chlorophyll-a ratio in microalgae and cyanobacteria: Implications for physiology and growth of phytoplankton, New Phytol. 106:1-34.

Geider RJ, McIntyre HL, Kana TM, 1998. A dynamic regulatory model of phytoplanktonic acclimation to light, nutrients, and temperature, Limnol. Oceanogr. 43:679-694.

Goering J, Alexander V, Haubenstock N, 1990. Seasonal variability of stable carbon and nitrogen isotope ratios of organisms in a North Pacific Bay. Estuar. Coast. Shelf S. 30:239-260.

Grashoff K, Ehrhardt M, Kremling K, 1992. Methods of seawater analysis. Verlag Chemie, New York: 419 pp.

Grey J, Jones RI, 2001. Seasonal changes in the importance of the source of organic matter to the diet of zooplankton in Loch Ness, as indicated by stable isotope analysis. Limnol. Oceanogr. 46:505-513.

Hall SJ, Raffaelli DG, 1993. Food webs: theory and reality. Adv. Ecol. Res. 24:187-239.

Hamilton SK, Lewis WM, 1992. Stable carbon and nitrogen isotopes in algae and detritus from the Orinoco River flood plain, Venezuela. Geochim. Cosmochim. Acta 56:42374246.

Head EJH, Harrison WG, Irwin BI, Horne EPW, Li WKW, 1996. Plankton dynamics and carbon flux in an area of upwelling off the coast of Morocco. Deep-Sea Res. PT I 43:1713-1738.

Heath MR, Richardson K, Kiørboe T, 1990. Optical assessment of phytoplankton nutrient depletion. J. Plankton Res. 12:381-396.

Hedges JI, Keil RG, Benner R, 1997. What happens to terrestrial organic matter in the ocean? Org. Geochem. 27:195-212.

Herman PMJ, Heip CHR, 1999. Biogeochemistry of the maximum turbidity zone of estuaries (MATURE): Some conclusions. J. Marine Syst. 22:89-104.

Heip CHR, Goosen NK, Herman PMJ, Kromkamp J, Middelburg JJ, Soetaert K, 1995. Production and consumption of biological particles in temperate tidal estuaries. Oceanogr. Mar. Biol. 33: 1-149.

Hellings L, Dehairs F, Tackx M, Keppens E, Baeyens W, 1999. Origin and fate or organic carbon in the freshwater part of the Scheldt estuary as traced by stable carbon isotope composition. Biogeochemistry 47:167-186. Hinz H, Moranta J, Balestrini S, Sciberras M, Pantin, JR, Monnington J, Zalewski A, Kaiser MJ, Skold M, Jonsson P, Bastardie F, Hiddink JG. 2017. Stable isotopes reveal the effect of trawl fisheries on the diet of commercially exploited species. Sci. Rep. 7:6334.

Hobson KA, Clark RG, 1992. Assessing avian diets using stable isotopes I: turnover of ${ }^{13} \mathrm{C}$ in tissues. Condor 94:181-88.

Hobson KA, Fisk A, Karnovsky N, Holst M, Gagnon JM, Fortier $\mathrm{M}, 2002$. A stable isotope $\left(\delta^{13} \mathrm{C}, \delta^{15} \mathrm{~N}\right)$ model for the North Water food web: implications for evaluating trophodynamics and the flow of energy and contaminants. Deep-Sea Res. Pt. II 49:5131-5150.

Howarth RW, Schneider WR, Swaney D, 1996. Metabolism and organic carbon fluxes in the tidal freshwater Hudson River. Estuaries 19:848-865.

Hussey NE, MacNeil MA, McMeans BC, Olin JA, Dudley SFJ, Cliff G, Wintner SP, Fenessy, ST, Fisk AT, 2014. Rescaling the trophic structure of marine food webs. Ecol. Lett. 17:239-250.

Jennings S, Pinnegar JK, Polunin NVC, Warr KJ, 2002. Linking size-based and trophic analyses of benthic community structure. Mar. Ecol. Prog. Ser. 226:77-85.

Jackson AL, Inger R, Bearhop S, Parnell A, 2009. Erroneous behaviour of MixSIR, a recently published Bayesian isotope mixing model: a discussion of Moore \& Semmens. Ecol. Lett. 12: E1-E5.

Kao SJ, Liu KK, 2000. Stable carbon and nitrogen isotope systematic in a human disturbed watershed (Lanyang-His) in Taiwan and the estimation of biogenic particulate organic carbon and nitrogen fluxes. Global Biogeochem. Cy. 14:189-198.

Kelly JR, Levin SA, 1986. A comparison of aquatic and terrestrial nutrient cycling and production processes in natural ecosystems, with reference to ecological consequences to some waste disposal issues, p. 165-203. In: G. Kullenberg (ed.), The role of oceans as a waste disposal option. NATO Advanced Research Workshop Series. D. Reidel Publ., Dordrecht.

Krishna MS, Naidu SA, Subbaiah ChV, Gawade L, Sarma VVSS, Reddy NPC, 2015. Sources, distribution and preservation of organic matter in a tropical estuary (Godavari, India). Estuaries Coasts 38:1032-1047.

Kromkamp J, Peene J, Rijswijk P, van Sandee A, Goosen N, 1995. Nutrients, light and primary production by phytoplankton and microphytobenthos in the eutrophic, turbid Westerschelde estuary (The Netherlands). Hydrobiologia 311: 9-19.

Landry MR, 1981. Switching between herbivory and carnivory by the planktonic marine copepod Calanus pacificus. Mar. Biol. 65:77-82.

Lammers JM, Reichart GJ, Middelburg JJ, 2017. Seasonal variability in phytoplankton stable carbon isotope ratios and bacterial carbon sources in a shallow Dutch lake. Limnol. Oceanogr. 62:2773-2787.

Layman CA, Araujo MS, Boucek R, Hammerschlag-Peyer CM, Harrison E, Jud ZR, Matich P, Rosenblatt AE, Vaudo JJ, Yeager LA, Post DM, Bearhop S, 2012. Applying stable isotopes to examine food-web structure: an overview of analytical tools. Biol. Rev. 87:545-562. 
Manini E, Fiordelmondo C, Gambi C, Pusceddu A, Danovaro $\mathrm{R}, 2003$. Benthic microbial loop functioning in coastal lagoons: A comparative approach. Oceanol. Acta 26:27-38.

Mariotti A, 1983. Atmospheric nitrogen is a reliable standard for natural ${ }^{15} \mathrm{~N}$ abundance measurements. Nature 303:685-687.

Mariotti A, Lancelot C, Billen G, 1984. Natural isotopic composition of nitrogen as a tracer of origin for suspended matter in the Scheldt estuary. Geochim. Cosmochim. Acta 48:549-555.

Matson EA, Brinson MM, 1990. Stabile carbon isotopes and the $\mathrm{C}: \mathrm{N}$ ratio in the estuaries of' the Pamlico and Neuse Rivers, North Carolina. Limnol. Oceanogr. 35:1290-1300.

Matthews B, Mazumder A, 2003. Compositional and inter-lake variability of zooplankton affect baseline stable isotope signatures. Limnol. Oceanogr. 48:1977-1987.

Matthews B, Mazumder A, 2006. Habitat specialization and the exploitation of allochthonous carbon by zooplankton. Ecology 87:2800-2812.

Meili M, Kling GW, Fry B, Bell RT, 1996. Sources and partitioning of organic matter in a pelagic microbial food web inferred from the isotopic composition $\left(\delta^{13} \mathrm{C}\right.$ and $\left.\delta^{15} \mathrm{~N}\right)$ of zooplankton species. Arch. Hydrobiol. Special Issues Adv. Limnol. 48:53-61.

Middelburg JJ, 2014. Stable isotopes dissect aquatic food webs from the top to the bottom. Biogeosciences 11:2357-2371.

Middelburg JJ, Herman PMJ, 2007. Organic matter processing in tidal estuaries. Mar. Chem. 106:127-147.

Middelburg JJ, Nieuweuwenhuize J, 1998. Carbon and nitrogen stable isotopes in suspended matter and sediments from the Schelde Estuary. Mar. Chem. 60: 217-225.

Minagawa M, Wada E, 1984. Stepwise enrichment of ${ }^{15} \mathrm{~N}$ along food chains: further evidence and the relation between ${ }^{15} \mathrm{~N}$ and animal age. Geochim. Cosmochim. Acta 48:1135-1140.

Montagnes DJS, Berges JA, Harrison PJ, Taylor FJR, 1994. Estimating carbon, nitrogen, protein and chlorophyll $a$ from volume in marine phytoplankton. Limnol. Oceanogr. 39:1044-1060.

Nixon SW, Oviatt CA, Frithsen J, Sullivan B, 1986. Nutrients and the productivity of estuarine and coastal marine ecosystems. J. Limnol. Soc. South Africa 12:43-71.

Ohman MD, Runge JA, 1994. Sustained fecundity when phytoplankton resources are in short supply: Omnivory by Calanus finmarchicus in the Gulf of St Lawrence. Limnol. Oceanogr. 39:21-36.

Owens NJP, 1985. Variations in the natural abundance of ${ }^{15} \mathrm{~N}$ in estuarine suspended particulate matter: a specific indicator of biological processing. Estuar. Coast. Shelf Sci. 20: 505510.

Parnell A, Jackson A, 2008. Siar: Stable Isotope Analysis in R. R Package Version 3.3, http://cran.r-project.org/web/ packages/siar/siar.pdf

Parnell AC, Inger R, Bearhop S, Jackson AL, 2010. Source partitioning using stable isotopes: Coping with too much variation. PLoS One 5:e9672.

Peterson BJ, Fry B, 1987. Stable isotopes in ecosystem studies. Annu. Rev. Ecol. Syst. 18:293-320.

Pinnegar JK, Polunin NVC, 1999. Differential fractionation of $\delta^{13} \mathrm{C}$ and $\delta^{15} \mathrm{~N}$ among fish tissues: implications for the study of trophic interactions. Functional Ecol. 13:225-231.

Post DM, 2002. Using stable isotopes to estimate trophic position: Models, methods, and assumptions. Ecology 83:703-718.

Prasad MHK, Sarma VVSS, Sarma VV, Krishna MS, Reddy NPC, 2013. Carbon dioxide emissions from the Tropical Dowleiswaram Reservoir on the Godavari River, South East of India. J. Water Res. Prot. 5:534-545.

Pope JG, Shepherd JG, Webb J, 1994. Successful surf-riding on size-spectra: the secret of survival in the sea. Philos. T. R. Soc. B 343:41-49.

Richard, P, Riera P, Galois R, 1997. Temporal variations in the chemical and carbon isotope compositions of marine and terrestrial organic inputs in the bay of Marennes-Oléron, France. J. Coastal Res. 13:879-899.

Richey JE, Melack JM, Aufdenkampe AK, Ballester VM, Hess LL, 2002. Outgassing from Amazonian rivers and wetlands as a large tropical source of atmospheric $\mathrm{CO}_{2}$. Nature 416:617-620.

Santer B, Sommerwerk N, Grey J, 2006. Food niches of cyclopoid copepods in eutrophic PluBsee determined by stable isotope analysis. Arch. Hydrobiol. 167:301-316.

Sarma VVSS, Arya J, Subbaiah ChV, Naidu SA, Gawade L, Praveen Kumar P, Reddy NPC, 2012. Stable isotopes of carbon and nitrogen in suspended matter and sediments from the Godavari estuary. J. Oceanogr. 68:307-319.

Sarma VVSS, Gupta SNM, Babu PVR, Acharya T, Harikrishnachari N, Vishnuvardhan K, Rao NS, Reddy NPC, Sarma VV, Sadhuram Y, Murty TVR, Kumar MD, 2009. Influence of river discharge on plankton metabolic rates in the tropical monsoon driven Godavari estuary, India. Estuar. Coast. Shelf S. 85:515-524.

Sarma VVSS, Krishna MS, Prasad VR, Kumar BSK, Naidu SA, Rao GD, Viswanadham R, Sridevi T, Kumar PP, Reddy NPC, 2014. Distribution and sources of particulate organic matter in the Indian monsoonal estuaries during monsoon. J. Geophys. Res. 119:2095-2111.

Sarma VVSS, Prasad VR, Kumar BSK, Rajeev K, Devi BMM, Reddy NPC, Sarma VV, Kumar MD, 2010. Intra-annual variability in nutrients in the Godavari estuary, India. Cont. Shelf Res. 30:2005-2014.

Sigman DM, Altabet MA, Mc Corkle DC, Francois R, Fischer G, 2000. The $\delta^{15} \mathrm{~N}$ of nitrate in the Southern Ocean: Nitrogen cycling and circulation in the ocean interior. J. Geophys. Res. 105:19599-19614.

Smith SV, Hollibaugh JT, 1993. Coastal metabolism and the oceanic organic carbon balance. Rev. Geophys. 31:75-89.

Soetaert K, Herman PMJ, 1995a. Carbon flows In the Westerschelde estuary (The Netherlands) evaluated by means of an ecosystem model (MOSES). Hydrobiologia 311:247-266.

Soetaert K, Herman PMJ, 1995b. Nitrogen dynamics in the Westerschelde estuary (SW Netherlands) estimated by means of the ecosystem model MOSES. Hydrobiologia 311:225-246.

Sridevi B, Sarma VVSS, Murty TVR, Sadhuram Y, Reddy NPC, Vijayakumar K, Raju NSN, Jawahar Kumar Ch, Raju YSN, Luis R, Kumar MD, and Prasad KVSR, 2015. Variability in stratification and flushing times of the gautami-Godavari estuary, India. J. Earth Sys. Sci. 124:993-1003.

Stowasser G, Atkinson A, McGill RAR, Phillips AR, Collins MA, Pond DW, 2012. Food web dynamics in the Scotia Sea 
in summer: A stable isotope study. Deep-Sea Res. Pt. II 5960:208-221.

Suzuki KW, Ueda H, Nakayama K, Tanaka M, 2013. Spatiotemporal dynamics of stable carbon isotope ratios in two sympatric oligohaline copepods in relation to the estuarine turbidity maximum (Chikugo River, Japan): implications for food sources. J. Plankton Res. 36:461-474.

Suzuki R, Ishimaru T, 1990. An improved method for the determination of phytoplankton chlorophyll using $\mathrm{N}, \mathrm{N}-$ dimethylformamide. J. Oceanogr. 46:190-194.

Thompson PA, Guo MX, Harrison PJ, 1992. Effects of variation in temperature. I. On the biochemical composition of eight species of marine phytoplankton. J. Phycol. 28:481-488.

Van Oevelen D, Soetaert K, Heip CHR, 2012. Carbon flows in the benthic food web of the Porcupine Abyssal plain: The (un)importance of labile detritus in supporting microbial and faunal carbon demands. Limnol. Oceanogr. 7:645-664. Vander-Zanden MJ, Cabana G, Rasmussem JB, 1997. Comparing trophic position of freshwater fish calculated using stable nitrogen isotope ratios $\left(\delta^{15} \mathrm{~N}\right)$ and literature dietary data. Can. J. Fish Aquat. Sci. 54:1142-1158.

Vijith VD, Sundar D, Shetye SR, 2009. Time-dependence of salinity in monsoonal estuaries. Estuar. Coast. Shelf S. 85:601-608.

Wollast R, 1998. Evaluation and comparison of the global carbon cycle in the coastal zone and in the open ocean, $\mathrm{p}$. 213-252. In: K.H. Brink and A.R. Robinson (eds.), The sea: The global coastal ocean. Processes and methods. J. Wiley $\&$ Sons, New York.

Wollast R, Mackenzie FT, 1989. Global biogeochemical cycles and climate, p. 453-473. In: A. Berger (ed.), Climate and geo-sciences. Kluwer Academic Publishers, Dordrecht. 